D) Check for updates

Cite this as: $B M J$ 2021;373:n1620 http://dx.doi.org/10.1136/bmj.n1620

Published: 24 June 2021

\section{Covid-19: How the UK is using lateral flow tests in the pandemic}

This Feature (BMJ 2021;372:n287, 4 February 2021, doi:) has been corrected to remove the name of a company whose staff were wrongly described as having been involved in NHS Test and Trace lateral flow testing. 